be an absorbing topic for anyone who is interested in the fascinating panorama of human progress.

In addition to the presidential address, lectures were given by six members of the academic staff of the University. Prof. G. Stephenson conducted a party over the new Civic Design Building. This was a most interesting experience as it allowed the visitors to understand the principles which are governing the many unusual features incorporated into the building. In the lecture which followed, Prof. Stephenson showed some examples of actual and projected planning from the early seventeenth century onwards, and followed this by discussing the problems facing those who are dealing with the re development of large cities at the present time, from which it was evident that those who would rationalize the lay-out of Greater London have an almost impossible task.

Prof. R. M. Gordon welcomed the Association to the "oldest School of Tropical Medicine in the world". He said that during the fifty-two years of its existence, the School has been called upon to investigate many problems of tropical medicine. In most cases it proved to be the non-medical biologist who led the way which later the physician followed. Hence the necessity for the combination of medicine and biology in the field of research in tropical medicine. Prof. Gordon then described two investigations being carried out at the present time in Africa, in which he is being helped by Prof. T. H. Davey, who later in the morning showed a film on "Ngana" (trypanosomiasis infection of animals in Africa).

The first investigation is being conducted in the Gezira, the vast cotton-growing area of the AngloEgyptian Sudan. Last year a world record crop was almost lost because of labour shortage attributed to the ill-health caused by schistosomiasis or bilharziasis. This worm infection invades the bladder and causes hrmorrhage; the eggs of the worm pass out in the urine, and if they reach water they hatch out and undergo further development in a freshwater snail. After some six weeks development the larva escapes back into the water and in its new form is capable of boring through the unbroken skin of anyone coming in contact with the water. The problems involved are so many that it was recommended that a research team consisting of a medical man and a freshwater ecologist should be appointed to co-operate with the large and highly skilled team of botanists and chemists now serving with the Gezira Cotton Scheme. It is pleasing to record that the Sudan Government has agreed to the appointment of such a team.

The second investigation is being carried out in the Cameroons. This area, though free from malaria and, on the whole, very healthy, is subject to loiasis, due to the loa-loa worm. The female worm lives in the human body and produces larvæ which get into the blood stream, from which they are taken up by the extremely common biting fly, Chrysops, known locally as the red fly. These biting flies then transfer the larvæ to another human subject, where the lifecycle is continued, producing much invaliding and suffering among both the native and the European populations. As the flies live in the forest canopy some $60 \mathrm{ft}$. above ground level and feed on the blood of monkeys, it seems that humans are only attacked on sight. Thus the forest canopy could be cleared back from human habitations provided sufficient undergrowth remained to keep the human population invisible to the flies. With insufficient knowledge, widespread control might be dangerous. Hence the need for the combined efforts of medical men and biologists to solve this problem.

Prof. C. E. H. Bawn startled his audience by saying that all chemical reactions are oxidations and reductions, and that the uptake of oxygen is one of the fundamental activities both of Nature and of chemistry. He described in detail some of the work carried out in the Chemistry Department of the University and showed how many reactions depend upon the formation of free radicals and of the derivatives of hydrogen peroxide.

Dr. J. D. Craggs thrilled his audience with lightning: displays. Dr. H. D. Parbrook surveyed the whole field of acoustics and indicated that the classical work of Sabine is now considered inadequate to describe the acoustic characteristics of a building, the simplest form of which demands equations involving 65 functions.

Dr. J. W. Jones described and showed a film of his original work on the spawning of salmon. This was a brilliant lecture.

The customary exhibitions were held, including on $\theta$ of apparatus devised by members. This, as usual, showed many ingenious devices all of which, this year, were of use for the younger pupils. In addition, the Nuclear Physics Department of the University was open for inspection, showing the giant cyclotron under construction. The Engineering Department gave a demonstration and the Physies Department showed a wide range of experiments which was greatly appreciated.

Nearly thirty teaching films were shown, and some of the senior pupils of the local grammar schools were invited to see them.

The Mersey Docks and Harbour Board invited a party to see its installations, and many firms in the neighbourhood conducted parties over their works.

On January 3, the Lord Mayor and the Lady Mayoress of Liverpool gave a civic welcome in the Town Hall to the Association. This was a most brilliant occasion, in the magnificent setting which the old Georgian suite of rooms permits.

Finally, the Vice-Chancellor invited the Association to a reception in the University. This was a charming event which included a recital in the delightful Arts Theatre.

Discussions, both formal and informal, filled the remaining time, and one can be assured that the teaching of science in all parts of Britain will have been stimulated by the excellence of this annual gathering of the Science Masters' Association.

William G. Rhodes

\section{FURTHER EDUCATION AND THE NEEDS OF GREAT BRITAIN}

TN his Will Harvey Memorial Lecture on "The Place of Further Education in the Public Services", given in the City Training College, Sheffield, on September 29, Sir Harold Hartley suggested that further education should be conceived not as a compound of vocational training with education for leisure but as education for co-operation and efficiency, for an understanding of the issues we face to-day, and for the defence of individual freedom and justice. In Great Britain national service in the Armed Forces has presented a new opportunity and fresh responsibilities, and it is a challenge to the Services so to use those vital 
years in a young man's life that he will look back on them with pride and affection in the same sort of way that many men do to their undergraduate days.

Much is already being done in private industry, but Sir Harold thinks that the biggest problems facing the nationalized industries in Britain are those of human relations, and to these the continuous process of further education at all levels is the answer. The main objective of such education must be the improvement of human relations, the establishment of mutual confidence and community of interest and a realization of the difficulties which Britain has to face and their inevitable and apparently frustrating consequences. In no other way is it possible to hope to escape from the misunderstandings and mistakes which ultimately affect everyone adversely.

Some day it must be realized that the inescapable effect of industrial disputes and restrictive practices is to lower the standard of living. Sir Harold reviewed briefly what is already being done in Great Britain to meet this need in the nationalized industries and the Civil Service, and he quoted with approval Sir Fred Clarke's view that the essence of adult education lies in its appeal to the adult student as a commitment to action. Such a student wants to know what he is to do, both as a person and as a citizen, and the objective should therefore be, not so much formulated knowledge, but rather a rational interpretation of experience.

In bringing the Lecture to a conclusion, Sir Harold insisted that the two problems are interdependent, one of increased productivity and thus retaining for Great Britain its place in the world to-day and its standards of living and way of life, and the other of curing the maladjustments and lack of mutual confidence in a rapidly changing society. The best hope of securing real community of interest and giving individual satisfaction lies in joint consultation and recognition of the contribution that each individual can. make and his responsibility to do so. The new range of responsibilities that joint consultation implies can only be met by opening a new chapter in education in Great Britain, both for management and for the trade unions. This is the most urgent task for further education and its immediate opportunity.

\section{TRAINING OF SUPERVISORS AND OF ORERATIVES IN INDUSTRY}

TAKEN together, the two Productivity Team 1 reports*, on the training of supervisors and of operatives respectively, form a counterpart to the report on trade schools of the Continent issued as a result of a visit twenty years ago by two Board of Education inspectors, A. Abbott and J. E. Dalton. Indeed, one of their most interesting features is the extent to which the recommendations of the Productivity Teams reiterate what was urged by Mr. Abbott in his subsequent book "Education for Industry and Commerce in England". There we find the same stress laid on the bearing of technical education on industrial efficiency, economic recovery * Productivity Reports. Training of Operatives. Report of one of
four Specialist Teams which visited the United States of America in 1951 to study Problems of Training for Industry. Pp. xii +52.38 . Training of Supervisors. Report of a visit to the U.S.A. in 1951 of a Specialist Team to study Supervisor Training and Selection. Pp.
viil +56. 2s. $6 d$. (London and New York: Anglo-A merican Council on Productivity, 1951.) and the maintenance of standards of living; thus early was the inefficiency of some industries attributed to their failure to utilize the scientific knowledge available to them. That failure was, it is true, in Mr. Abbott's view, due to those industries not employing enough men with the necessary wide and thorough scientific training, but by and large there is a disturbing similarity between the reflexions provoked twenty years ago by an examination of technical education on the Continent in comparison with that in Great Britain and the impressions derived by the Productivity Teams in their examination of the American scene last year.

There are differences and changes, especially in detail, but the generalization is broadly true, and it does not augur well for the industrial and economic future of Britain that so little advance should be recorded in two decades. When all allowance is made for the differences in background, and between the American and the British way of life, both these reports leave the impression that the main difference between the American scene and the British scene is psychological. In all types of training, the eagerness of the individual to be trained is a basic assumption in the United States: the individual readily accepts a way of life in which his frosperity is directly proportional to his own efforts and ability, and there is a stimulating atmosphere of vitality which allows no practices to be unalterably established. New practices are constantly being evolved and old ones are scrapped without regret as soon as new and better ones appear.

Another significant passage in the report on the training of operatives is that referring to status in American industry. It appears that there is a steady movement towards a position where all those in supervisory posts will have college or university degrees, all journeymen and apprentices will be high-school graduates and most other employees will have had high-school education up to the age of seventeen or eighteen. "If we remember, too, that many, perhaps most, of the best pupils from the high schools enter industry (most of our best pupils enter the professions), we may ponder on the profound effect this trend is having and will continue to have on the efficiency of American industry." Much of the development, particularly in the training of teachers, has been recent: in fifty years the highschool population has increased from about one-third of a million to more than six millions, and is now about 25 per cent of the total enrolment instead of 2.5 per cent. Any country might well be proud of what has been accomplished, and the Team records further its considered opinion that educational policy in the United States is being so shaped that these achievements will be censolidated and progress main. tained throughout the second half of the century.

The report notes that the American approach to vocational training is marked by a refreshing willingness to experiment and by a freedom from tradition and prejudice. Both management and labour recognize the urgency of the current training problem in industry ; employers regard training as an investment, and unions are willing to vary regulations as circumstances demand. The value of training schemes, however, depends not only on the degree of such goodwill but also on the degree in which employers and unions succeed in working together; but the fairly free general movement from lower to higher paid jobs encourages the worker to take advantage of the training offered. 